\title{
Investigation of the Self-Efficacy Beliefs of Turkish Language and Literature Teachers in Practicing Constructivist Approach in Terms of Various Variables
}

\author{
Fatih Veyis ${ }^{1}$ \\ ${ }^{1}$ Kazım Karabekir Education Faculty, Atatürk University, Erzurum, Turkey \\ Correspondence: Fatih Veyis, Kâzım Karabekir Education Faculty, Atatürk University, Erzurum, Turkey. E-mail: \\ fatih.veyis@atauni.edu.tr
}

Received: January 14, 2020

Accepted: February 25, 2020

Online Published: June 11, 2020

doi:10.5539/ies.v13n7p47

URL: https://doi.org/10.5539/ies.v13n7p47

\begin{abstract}
It is a scientifically and developmentally undeniable reality that the educational activities that guide education and training activities and aim to raise the nation according to the requirements of the age and keep up with the necessary arrangements for this purpose. With the periodic developments in the world, the transformation in the philosophy of education and understanding of education has brought along the application of new approaches and understandings in education. The constructivist approach that started to be applied in education with these developments is also one of the new educational approaches. Constructivist understanding is defined as a process in which students are actively involved in educational activities and new information is built on pre-learning. Constructivism is a contemporary understanding that covers all kinds of practices that the student can actively engage in the learning process, and it emphasizes that education can be successful to the extent that it can serve individual differences. It has been fifteen years since the practices on constructivism started to be implemented in our country. During this period and as a point reached, it is a question of how much this understanding is applied. With this research, it is aimed to examine the self-efficacy beliefs of Turkish language and literature teachers towards applying constructivist approach in terms of various variables.
\end{abstract}

Keywords: constructivist approach, self-efficacy belief, Turkish language, literature education

\section{Introduction}

\subsection{Constructivist Approach and Learning}

The theoretical foundations laid by Lev S. Vygotsky, Jean Piaget, John Dewey, Jerome Bruner and E. Von Glasersfeld emerged under the influence of progressive education philosophy, which is a reflection of education in pragmatist philosophy. The concept of constructivism is not a teaching method in itself, but a philosophy of knowledge and learning theory that develops within the framework of the question of "How do people learn?" (Taşpınar, 2017). Altun and Çolak (2011) define constructivism within the framework of learning theories as "A learning theory based on the view that individuals are the directors of their own learning processes and learn by building bridges between new information about their prior knowledge."

According to the constructivist learning theory, information is not something that can be integrated externally to people, the individual creates the information with his/her own mental and internal processes (Schunk, 2014). In other words, individuals are not empty barrels waiting to be filled, on the contrary, they are active organisms that investigate meanings (Koç \& Demirel, 2004, p. 174). Thus, there is no program that can be applied equally to everyone in education processes, and differences in students' learning styles and pre-learning should be taken into account.

According to the constructivist approach, learning is a process that takes place in the mind of the individuals and they do not receive the information as it is from the outside, but the information is structured by some mental processes. This structuring process is about associating the previously learned information with the newly learned information in mind, creating a meaning about the incoming information and making the information unique. The most important feature of constructivist education in this aspect is that it gives the learner the opportunity to structure, construct, interpret and improve the information (Yildızlar, 2009). 
The main determinants of the methods and techniques to be applied in the constructivist teaching process are shaped according to the basic principles of constructivism, the objectives of the course and student needs. Considering the views of constructivism about the individual's learning process, the course process can be examined in three parts: exploring knowledge basically, creating concepts and applying. The implementation of this plan in the lesson can be realized by following learning models such as 3E, 5E, 7E (Akınoğlu, 2012). In addition, contemporary teaching methods and strategies such as in-class discussions, peer teaching, collaborative learning, case study, role playing, drama, problem-based learning and project studies are preferred in constructivist learning environments, which are characterized as multi-dimensional classes.

"Process" has an important place in constructivist teaching approach. The learning needs of students can emerge in the process and teaching objectives can be determined in the process. In addition to all these, one of the most important features of constructivist education is that assessment is simultaneous with learning processes. In constructivism, the assessment is made throughout the entire learning process, not at the end of the semester. The student is also included in the evaluation process with personal evaluation and peer evaluation applications. While evaluating in constructivist assessment, learning continues at the same time. In addition to using traditional assessment tools for learning purposes, individual and group evaluations, observation, performance evaluation, open-ended questions, personal development portfolios, personal interview, attitude and skill scales are used as measurement tools (Akınoğlu, 2012).

Constructivism opposes the views that emphasizes that only the environment is effective on the person in the learning processes and at the same time learning is realized only in the mind and the environment is not effective in this process. Considering these opinions, the constructivist approach proposes to educators that students should actively participate in their own learning processes and they should offer experiences that stimulate students' thoughts (Schunk, 2014).

\subsection{Student's Role in Constructivist Learning Environment}

In a curriculum prepared according to the constructivist approach, it is aimed primarily to provide permanent learning and to develop high-level thinking skills in the student. In such an approach, the student is in the center. As a learning subject, the student has some roles and responsibilities in reaching the determined goals. In their research which examines student and teacher responsibilities in constructivist education, Koç (2006) identified student roles in constructivist education environments as follows:

- Fulfilling responsibilities,

- Controlling the learning process:

1) Setting their own learning goals,

2) Accessing to information resources,

3) Deciding on the activities and duration,

4) Assessing themselves and their friends,

5) Determining their deficiencies,

- Interpreting the knowledge:

1) Reading from more and different sources,

2) Integrating new knowledge with prior knowledge,

3) Generating questions, asking questions,

4) Defending their ideas,

- Ability to work effectively with the group:

1) Making joint decisions,

2) Getting help from a friend,

- Effective communication with the teacher (p. 60).

As seen, student roles and responsibilities in constructivist learning environments are much more than in traditional learning environments. However, the responsibilities that the student is expected to fulfill in constructivist learning process are important in terms of making the student active in the process and ensuring permanent learning. Especially in cooperative learning processes, the ability of the students to access information by communicating, discussing, comparing what they have learned with peers, without being dependent on the 
teacher or an authority, are important skills needed in professional life. Such skills are also effective in the student's lifelong learning.

In terms of constructivist approach, learning is a social, situational, subjective, emotional, developmental and continuous process. It also emphasizes that the learners constantly discover knowledge, improve and change their mental structures. Thus, in constructivist learning, the information is structured in an individual and original way, and the learners develop themselves in a holistic and versatile way (Akınoğlu, 2012).

\subsection{Teacher Role in Constructivist Learning Environment}

The role of teacher in constructivist teaching is expressed as "guiding" in a broad sense. This statement does not reduce the effectiveness and authority of the teacher in the classroom, but on the contrary, it creates more demands for the teacher. Even when the students work on their own without the need for teacher's intervention, the teacher should make sure that the students have the skills and materials they need and ensure that they reach these skills and materials when necessary (Schunk, 2014). When the roles and skills of teachers in constructivist learning environments are examined in detail, it is seen that they are largely in line with the goals of constructivist education. Accordingly, teacher roles in constructivist learning environments can be listed as follows (Akınoğlu, 2012; Oğuz, 2009):

- Associates students' pre-learning with new information.

- Encourages students to ask questions and to question what they have learned.

- Allows students to structure their newly learned information themselves.

- Enables students to actively participate in the lesson.

- Includes activities that will enable students to learn from each other and in cooperation in the lesson.

- Handles the topics in a spiral manner, taking into account the individual speed and abilities of the students.

- Provides a democratic educational environment in the classroom.

- Creates teaching activities on real life problems.

- Uses methods and techniques that take the student to the center and ensure the active participation of the student.

- Determines projects that will inspire students and encourage them to research and discover. Improves problem solving skills of the students.

- Includes activities that enable students to think creatively and critically.

- Allows students to develop different perspectives on a topic or problem.

- Guides students to apply what they learn to new situations and use them in their own lives.

- Tries to understand the feelings, thoughts, beliefs and attitudes of the students and allows students to reflect their individual characteristics.

- Takes into account the teaching process, the products and observations that students present in the process when evaluating students.

- Uses a variety of measurement tools (observation, personal interview, open-ended questions, development portfolio, etc.), not a single measurement tool in the evaluation process.

- Allows students to evaluate themselves, their peers, and the teaching process.

Teachers may encounter some difficulties in implementing constructivist teaching. The first of these is the inadequacy of field knowledge and the insufficient pedagogical skills. In addition to this, not giving enough importance to this knowledge field in teacher training programs, the fact that the curriculum is not prepared in accordance with the constructivist approach and the school management does not support the constructivist teaching practices sufficiently in the professional life can be counted among the problems faced by teachers. This research, which was conducted for Turkish language and literature teachers, was carried out with the aim of determining teachers' perceptions about applying constructivist approach. The self-efficacy beliefs of Turkish language and literature teachers regarding the constructivist approach were examined in terms of variables such as professional seniority, age, gender, graduated faculty, the type of school they work in, the number of in-service trainings they attended, education levels (bachelor, master, doctorate). 


\section{Method}

\subsection{Research Method}

This research, which is conducted to determine the self-efficacy perceptions of Turkish language and literature teachers working in secondary education institutions in terms of various variables, is a descriptive study in correlational survey. Survey models are research approaches that aim to describe a situation that exists in the past or still as it exists. The phenomenon, individual or object that is the subject of the research is tried to be defined in its own conditions and as it is. No effort is made to change or influence them in any way. General survey model among survey models are correlating arrangements made on the whole population or a group or sample to be taken from a population in order to make a general judgment about the population (Karasar, 2009, pp. 77-79).

\subsection{Population and Sampling}

Turkish language and literature teachers constitute the population of the research. The sample consists of 253 Turkish language and literature teachers working in secondary education institutions and chosen randomly and accessible during the research process. The results of the research are limited to Turkish language and literature teachers working in secondary education institutions.

\subsection{Data Collection}

The research data were obtained by using the "Self-Efficacy Perceptions of Teachers About the Implementation of The Constructivist Approach Scale" developed by Eskici and Özen (2013) and by getting the necessary permissions.

\subsection{Data Analysis}

The data obtained in the research were analyzed by using appropriate statistical tests through SPSS 22 software.

\section{Findings}

\subsection{Do Self-Efficacy Perceptions of the Teachers Regarding Constructivist Teaching Differ Significantly} According to Their Gender?

Independent Sample t Test was applied to determine whether teachers' perceptions on constructivist teaching show statistically significant differences according to their gender, and the findings obtained are presented in Table 1 . As a result of the Levene Test conducted for the homogeneity of the data, which is the prerequisite of the analysis, it was seen that homogeneity condition was met finding that the guiding dimension is $\mathrm{F}=1.479, \mathrm{p}>.05$, the activating student dimension is $\mathrm{F}=3.072, \mathrm{p}>.05$, the encouraging to thing is $\mathrm{F}=.381, \mathrm{p}>.05$, alternative assessment is $\mathrm{F}=.389, \mathrm{p}>.05$.

Table 1. Findings related to gender

\begin{tabular}{|c|c|c|c|c|c|c|}
\hline & Gender & $\mathrm{N}$ & $\bar{X}$ & Ss & $\mathrm{t}$ & $\mathrm{p}$ \\
\hline \multirow{2}{*}{ Guiding } & Female & 118 & 35.03 & 4.40 & \multirow{2}{*}{3.842} & \multirow{2}{*}{.000} \\
\hline & Male & 135 & 37.28 & 4.84 & & \\
\hline \multirow{2}{*}{ Activating student } & Female & 118 & 32.43 & 3.93 & \multirow{2}{*}{2.479} & \multirow{2}{*}{.014} \\
\hline & Male & 135 & 33.71 & 4.24 & & \\
\hline \multirow{2}{*}{ Encouraging to think } & Female & 118 & 29.28 & 3.33 & \multirow{2}{*}{1.955} & \multirow{2}{*}{.052} \\
\hline & Male & 135 & 30.12 & 3.40 & & \\
\hline \multirow{2}{*}{ Alternative assessment } & Female & 118 & 19.46 & 2.63 & \multirow{2}{*}{3.871} & \multirow{2}{*}{.000} \\
\hline & Male & 135 & 20.79 & 2.80 & & \\
\hline
\end{tabular}

When Table 1 is examined, as a result of Independent Samples t Test conducted to determine whether teachers' self-efficacy perceptions differ significantly with respect to gender variable, a significant differentiation was found in terms of gender variable in all subdimensions except for the subdimension of encouraging thinking. It was observed that the difference in the guiding sub-dimension $\mathrm{t} 251=3.842, \mathrm{p}<.05$, the activating student dimension $\mathrm{t} 251=2.497, \mathrm{p}<.05$, and the alternative assessment dimension $\mathrm{t} 251=3.871, \mathrm{p}<.05$ was found to be in favor of male teachers by examining the mean scores. In the encouraging to think sub-dimension (t $251=1.955, \mathrm{p}>.05$ ), there was no significant difference regarding the gender variable.

3.2 Do the Self-Efficacy Perceptions of the Teachers Regarding Constructivist Teaching Approach Differ Significantly According to the Faculty They Graduated From? 
Independent Sample t Test was applied to determine whether teachers' perceptions on constructivist teaching show statistically significant differences according to the faculty they graduated from, and the findings obtained are presented in Table 2. As a result of the Levene Test conducted for the homogeneity of the data which is the prerequisite of the analysis, the dimension of guiding $\mathrm{F}=3.941, \mathrm{p}<.05$ did not meet this condition; it was found that the activating student dimension was $\mathrm{F}=.205, \mathrm{p}>.05$, the encouraging to think dimension was $\mathrm{F}=1.956$, $\mathrm{p}>.05$, alternative assessment dimension was $\mathrm{F}=1.352, \mathrm{p}>.05$. Mann Whitney $\mathrm{U}$, one of the nonparametric tests, was done for the guiding dimension, and the findings are given in Table 3.

Table 2. Findings related to the graduated faculty variable

\begin{tabular}{|c|c|c|c|c|c|c|}
\hline & Faculty & $\mathrm{N}$ & $\bar{X}$ & Ss & $\mathrm{t}$ & $\mathrm{p}$ \\
\hline \multirow{2}{*}{ Activating student } & Education & 161 & 37.10 & 4.05 & \multirow{2}{*}{2.08} & \multirow{2}{*}{.041} \\
\hline & Literature & 92 & 33.14 & 4.31 & & \\
\hline \multirow{2}{*}{ Encouraging to think } & Education & 161 & 31.89 & 3.58 & \multirow{2}{*}{2.96} & \multirow{2}{*}{.037} \\
\hline & Literature & 92 & 29.44 & 3.02 & & \\
\hline \multirow{2}{*}{ Alternative assessment } & Education & 161 & 20.22 & 2.59 & \multirow{2}{*}{.365} & \multirow{2}{*}{.715} \\
\hline & Literature & 92 & 20.09 & 3.15 & & \\
\hline
\end{tabular}

When Table 2 is examined, it was seen that self-efficacy perception significantly differentiated in the sub-dimensions of activating the student $\mathrm{t} 251=2.08, \mathrm{p}<.05$ and encouraging to think $\mathrm{t} 251=2.96, \mathrm{p}<.05$ as a result of Independent Samples t Test conducted to determine whether teachers' self-efficacy perceptions on constructivist teaching differ significantly according to the graduated faculty variable. When the source of the difference was analyzed, it was seen that it was in favor of the graduates of faculty of education. On the other hand, it was found that there was no significant difference in the alternative assessment subdimension $t_{251}=.365$, $\mathrm{p}>.05$.

Table 3. Findings Related to the Graduated Faculty Variable

\begin{tabular}{ccccccc}
\hline & Faculty & $\mathrm{N}$ & Mean Rank & Rank Sum & $\mathrm{U}$ & $\mathrm{p}$ \\
\hline \multirow{2}{*}{ Guiding } & Education & 161 & 131.11 & 21109.50 & \multirow{2}{*}{18743.500} & \multirow{2}{*}{.023} \\
& Literature & 92 & 119.80 & 11021.50 & & \\
\hline
\end{tabular}

When Table 3 is analyzed, It was determined that the guiding dimension $(U=18743.500, p<.05)$ showed a significant difference according to the graduated faculty variable and this difference was in favor of the graduates of faculty of education as a result of the Mann Whitney U Test conducted to determine whether the teachers' self-efficacy perceptions regarding constructivist teaching differ significantly according to the graduated faculty variable.

\subsection{Do the Self-Efficacy Perceptions of the Teachers Regarding Constructivist Teaching Approach Differ Significantly According to Their Participation in In-Service Training?}

Independent Sample t Test was applied to determine whether teachers' perceptions about constructivist teaching differ statistically or not according to their participation in in-service trainings, and the findings are presented in Table 4. As a result of the Levene Test conducted for the homogeneity of the data, which is the prerequisite of the analysis, it was determined that the guiding dimension is $\mathrm{F}=.014, \mathrm{p}>.05$, the activating student dimension is $\mathrm{F}$ $=.711, \mathrm{p}>.05$, the encouraging to think dimension is $\mathrm{F}=.081, \mathrm{p}>.05$ and the alternative assessment dimension is $\mathrm{F}=.010, \mathrm{p}>.05$, which provides the homogeneity condition. 
Table 4. Findings regarding participation in in-service training

\begin{tabular}{ccccccc}
\hline & Status & $\mathrm{N}$ & $\bar{X}$ & $\mathrm{Ss}$ & $\mathrm{t}$ & $\mathrm{p}$ \\
\hline \multirow{3}{*}{ Guiding } & I participated & 209 & 36.22 & 4.82 & & \\
& I haven't participated & 44 & 36.27 & 4.54 & -.071 & .944 \\
Activating student & I participated & 209 & 33.11 & 4.21 & & \\
& I haven't participated & 44 & 33.13 & 3.83 & -.035 & .972 \\
& I participated & 209 & 39.63 & 3.35 & & \\
Encouraging to think & I haven't participated & 44 & 30.20 & 3.57 & 4.116 & .031 \\
& I participated & 209 & 26.10 & 2.83 & & \\
Alternative assessment & I haven't participated & 44 & 20.52 & 2.61 & & \\
& & & & & & \\
& & & & & & \\
& & &
\end{tabular}

When Table 4 is analyzed, as a result of Independent Samples t Test conducted to determine whether teachers' self-efficacy perceptions regarding constructivist teaching differ significantly according to their participation in in-service training, it was determined that there was no statistically significant difference in terms of participation in in-service training in the guiding dimension $\mathrm{t} 251=-.071, \mathrm{p}>.05$ and the activating student dimension $\mathrm{t} 251=-$. $035, p>.05$; however, it was found that there was no statistically significant difference in terms of participating in in-service training in the encouraging to think dimension $\mathrm{t} 251=4.11$ and $\mathrm{p}<.05$ and the alternative assessment dimension $\mathrm{t} 251=2.90, \mathrm{p}<.05$.

\subsection{Do the Self-Efficacy Perceptions of the Teachers Regarding Constructivist Teaching Approach Differ} Significantly According to Having Computer Education During the Undergraduate Program?

Independent Sample t Test was applied to determine whether teachers' perceptions of constructivist teaching differ statistically or not according to having computer education during their undergraduate education, and the findings are presented in Table 5. As a result of the Levene Test conducted for the homogeneity of the data, the prerequisite of the analysis, it was determined that the guiding dimension is $\mathrm{F}=.063, \mathrm{p}>.05$, the activating student dimension is $\mathrm{F}=.195, \mathrm{p}>.05$, the encouraging to think dimension is $\mathrm{F}=.197, \mathrm{p}>.05$ and the alternative assessment dimension is $\mathrm{F}=.547, \mathrm{p}>.05$, which provided the homogeneity condition.

Table 5. Findings regarding having computer education during the undergraduate program

\begin{tabular}{|c|c|c|c|c|c|c|}
\hline & Status & $\mathrm{N}$ & $X$ & Ss & $\mathrm{t}$ & $\mathrm{P}$ \\
\hline \multirow{2}{*}{ Guiding } & I had & 180 & 180 & 4.82 & \multirow{2}{*}{1.288} & \multirow{2}{*}{.199} \\
\hline & I did not have & 73 & 35.62 & 4.61 & & \\
\hline \multirow{2}{*}{ Activating student } & I had & 180 & 33.12 & 4.12 & \multirow{2}{*}{.076} & \multirow{2}{*}{.940} \\
\hline & I did not have & 73 & 33.08 & 4.22 & & \\
\hline \multirow{2}{*}{ Encouraging to think } & I had & 180 & 29.87 & 3.46 & \multirow{2}{*}{1.021} & \multirow{2}{*}{.308} \\
\hline & I did not have & 73 & 29.38 & 3.20 & & \\
\hline \multirow{2}{*}{ Alternative assessment } & I had & 180 & 20.30 & 2.85 & \multirow{2}{*}{1.115} & \multirow{2}{*}{.266} \\
\hline & I did not have & 73 & 19.86 & 2.64 & & \\
\hline
\end{tabular}

When Table 5 is examined, as a result of Independent Samples t Test conducted to determine whether teachers' self-efficacy perceptions on constructivist teaching differed significantly according to having computer education status during undergraduate education, it was determined that there is no statistically significant difference in the guidance dimension $(\mathrm{t} 251=1.288, \mathrm{p}>.05)$, activating student dimension $(\mathrm{t} 251=.076, \mathrm{p}>.05)$, encouraging to think dimension $(\mathrm{t} 251=1.021, \mathrm{p}>.05)$ and alternative assessment dimension $(\mathrm{t} 251=1.115, \mathrm{p}>.05)$.

3.5 Do the Self-Efficacy Perceptions of the Teachers Regarding Constructivist Teaching Approach Differ Significantly According to Professional Seniority Variable?

Single Factor Variance Analysis (ANOVA) was done to determine whether teachers' perceptions on constructivist teaching differ according to professional seniority variable, and the findings are presented in Table 6 . Levene's test was conducted to determine whether the homogeneity condition of the variances, which is the prerequisite of ANOVA, was met, and it was determined that the guiding dimension is $\mathrm{F}_{(3,249)}=2.916, \mathrm{p}<.05$, the activating student dimension is $\mathrm{F}_{(3,249)}=.766, \mathrm{p}>.05$, the encouraging to think dimension is $\mathrm{F}_{(3,249)}=.778, \mathrm{p}>.05$ and alternative assessment is $\mathrm{F}_{(3,249)}=1.199, \mathrm{p}>.05$. Since the guiding dimension did not meet the requirement for homogeneity, Kruskal Wallis test was done, and the findings obtained are given in Table 7. 
Table 6. ANOVA findings related to the professional seniority variable

\begin{tabular}{|c|c|c|c|c|c|c|c|}
\hline & Professional Seniority & $\mathrm{N}$ & $X$ & Ss & $\mathrm{Sd}$ & $\mathrm{F}$ & $\mathrm{p}$ \\
\hline \multirow{4}{*}{$\begin{array}{l}\text { Activating } \\
\text { Student }\end{array}$} & $1-3$ years & 95 & 32.35 & 3.87 & \multirow{4}{*}{$3 / 249$} & \multirow{4}{*}{2.228} & \multirow{4}{*}{.085} \\
\hline & 4-6 Years & 43 & 32.93 & 4.21 & & & \\
\hline & 7-9 Years & 24 & 33.58 & 4.49 & & & \\
\hline & 10 Years and above & 91 & 33.87 & 4.22 & & & \\
\hline \multirow{4}{*}{$\begin{array}{c}\text { Encouraging to } \\
\text { Think }\end{array}$} & $1-3$ years & 95 & 29.50 & 3.27 & \multirow{4}{*}{$3 / 249$} & \multirow{4}{*}{4.060} & \multirow{4}{*}{.027} \\
\hline & 4-6 Years & 43 & 29.24 & 4.08 & & & \\
\hline & 7-9 Years & 24 & 36.54 & 3.03 & & & \\
\hline & 10 Years and above & 91 & 35.98 & 3.24 & & & \\
\hline \multirow{4}{*}{$\begin{array}{l}\text { Alternative } \\
\text { Assessment }\end{array}$} & $1-3$ years & 95 & 19.79 & 2.47 & \multirow{4}{*}{$3 / 249$} & \multirow{4}{*}{10.536} & \multirow{4}{*}{.016} \\
\hline & 4-6 Years & 43 & 19.93 & 3.21 & & & \\
\hline & 7-9 Years & 24 & 26.50 & 2.62 & & & \\
\hline & 10 Years and above & 91 & 25.60 & 2.93 & & & \\
\hline
\end{tabular}

When Table 6 is examined, as a result of ANOVA, which was conducted to determine whether teachers' perceptions on constructivist teaching differ significantly according to the professional seniority variable, the activating student dimension $\left(\mathrm{F}_{(3,249)}=2.228, \mathrm{p}>.05\right)$ did not differ significantly according to the professional seniority, but the encouraging to think $\left(\mathrm{F}_{(3,249)}=1,060, \mathrm{p}>.05\right)$ and alternative assessment dimensions $\left(\mathrm{F}_{(3,249)}=\right.$ $4.060, \mathrm{p}<.05$ ) were found to differ significantly according to the professional seniority variable. As a result of the Tukey test conducted to determine the source of the determined difference, it was determined that the average scores of those with 7-9 and 10 years of professional seniority were significantly higher than the other seniority groups.

Table 7. Kruskal Wallis findings related to the professional seniority variable

\begin{tabular}{ccccccc}
\hline Burnout & Professional Seniority & $\mathrm{N}$ & Mean Rank & $\mathrm{Sd}$ & $\mathrm{x}^{2}$ & $\mathrm{p}$ \\
\hline \multirow{4}{*}{ Guiding } & 1-3 years & 95 & 116.75 & & & \\
& 4-6 Years & 43 & 125.43 & & & \\
& 7-9 Years & 24 & 175.73 & 3 & 12.195 & .021 \\
& 10 Years and above & 91 & 163.51 & & & \\
\hline
\end{tabular}

When Table 7 is analyzed, it was found that the guiding dimension $(\mathrm{x} 2=12.19$, sd $=3, \mathrm{p}<.05)$ significantly differentiated according to the teachers' professional seniority as a result of the Kruskal Wallis $\mathrm{H}$ test conducted to determine whether the perceptions of teachers differ in terms of professional seniority. In order to determine the source of the difference, a two-samples $t$ test comparison was done, and it was determined that the point averages of those with 7-9 professional seniority and those with 10 years and above were significantly higher than the other seniority groups.

\subsection{Do the Self-Efficacy Perceptions of the Teachers Regarding Constructivist Teaching Approach Differ} Significantly According to the Type of School They Work at?

One-way analysis of variance (ANOVA) was conducted to determine whether teachers' perceptions on constructivist teaching differ according to the type of school they work at, and the findings obtained are presented in Table 8. To determine whether the homogeneity condition of the variances, which are the prerequisites of ANOVA, is met, Levene test was done, and it was determined that the guiding dimension is $\mathrm{F}_{(4,248)}=.634, \mathrm{p}>.05$, the activating student dimension is $\mathrm{F}_{(4,248)}=.190, \mathrm{p}>.05$, the encouraging to think dimension is $\mathrm{F}_{(4,248)}=1.306$, $\mathrm{p}>.05$ and alternative assessment dimension is $\mathrm{F}_{(4,248)}=.586, \mathrm{p}>.05$. 
Table 8. ANOVA findings regarding the variable of school type they work

\begin{tabular}{|c|c|c|c|c|c|c|c|}
\hline & School Type & $\mathrm{N}$ & $X$ & Ss & $\mathrm{Sd}$ & $\mathrm{F}$ & $\mathrm{p}$ \\
\hline \multirow{5}{*}{ Guiding } & Anatolian High School & 119 & 36.07 & 4.84 & \multirow{5}{*}{$4 / 248$} & \multirow{5}{*}{3.188} & \multirow{5}{*}{.041} \\
\hline & Vocational Technical High School & 63 & 36.59 & 5.18 & & & \\
\hline & $\begin{array}{l}\text { Science and Social Sciences High } \\
\text { School }\end{array}$ & 11 & 39.65 & 4.26 & & & \\
\hline & $\begin{array}{l}\text { Anatolian Imam Hatip High } \\
\text { School }\end{array}$ & 50 & 36.18 & 4.27 & & & \\
\hline & Multi-Program High School & 10 & 35.60 & 4.78 & & & \\
\hline \multirow{5}{*}{$\begin{array}{c}\text { Activating } \\
\text { Student }\end{array}$} & Anatolian High School & 119 & 32.80 & 4.27 & \multirow{5}{*}{$4 / 248$} & \multirow{5}{*}{2.327} & \multirow{5}{*}{.046} \\
\hline & Vocational Technical High School & 63 & 33.35 & 4.16 & & & \\
\hline & $\begin{array}{l}\text { Science and Social Sciences High } \\
\text { School }\end{array}$ & 11 & 37.29 & 4.35 & & & \\
\hline & $\begin{array}{l}\text { Anatolian Imam Hatip High } \\
\text { School }\end{array}$ & 50 & 33.50 & 3.76 & & & \\
\hline & Multi-Program High School & 10 & 33.20 & 4.63 & & & \\
\hline \multirow{5}{*}{$\begin{array}{l}\text { Encouraging to } \\
\text { Think }\end{array}$} & Anatolian High School & 119 & 29.19 & 3.73 & \multirow{5}{*}{$4 / 248$} & \multirow{5}{*}{3.554} & \multirow{5}{*}{.033} \\
\hline & Vocational Technical High School & 63 & 30.07 & 3.13 & & & \\
\hline & $\begin{array}{l}\text { Science and Social Sciences High } \\
\text { School }\end{array}$ & 11 & 36.15 & 3.12 & & & \\
\hline & $\begin{array}{c}\text { Anatolian Imam Hatip High } \\
\text { School }\end{array}$ & 50 & 30.46 & 2.74 & & & \\
\hline & Multi-Program High School & 10 & 29.90 & 3.51 & & & \\
\hline \multirow{5}{*}{$\begin{array}{l}\text { Alternative } \\
\text { Assessment }\end{array}$} & Anatolian High School & 119 & 20.18 & 3.05 & \multirow{5}{*}{$4 / 248$} & \multirow{5}{*}{4.027} & \multirow{5}{*}{.044} \\
\hline & Vocational Technical High School & 63 & 20.17 & 2.67 & & & \\
\hline & $\begin{array}{l}\text { Science and Social Sciences High } \\
\text { School }\end{array}$ & 11 & 17.92 & 2.98 & & & \\
\hline & $\begin{array}{c}\text { Anatolian Imam Hatip High } \\
\text { School }\end{array}$ & 50 & 20.18 & 2.32 & & & \\
\hline & Multi-Program High School & 10 & 20.30 & 2.98 & & & \\
\hline
\end{tabular}

When Table 8 is analyzed, As a result of ANOVA conducted to determine whether teachers' perceptions on constructivist teaching differ significantly according to the type of school they work at, it was determined that the guiding dimension $\mathrm{F}_{(4,248)}=3.18, \mathrm{p}<.05$, the activating student dimension $\mathrm{F}_{(4,248)}=2.37, \mathrm{p}<.05$, the encouraging to think dimension $\mathrm{F}_{(4,248)}=3.55, \mathrm{p}<.05$ and the alternative assessment dimension $\mathrm{F}_{(4,248)}=4.07, \mathrm{p}<.05$ differed significantly according to the type of school they work at. Tukey test was conducted to determine the source of the difference, and it was determined that the point averages of teachers working in Science and Social Sciences high schools were significantly higher than the teachers working in other schools.

\section{Results and Discussion}

In this study, which examines the self-efficacy perceptions of Turkish language and literature teachers on implementing the constructivist approach, it was determined that the gender variable significantly affects the self-efficacy perception about implementing the constructivist approach in terms of guiding, activating student and alternative assessment dimensions. It is concluded that male teachers' self-efficacy perceptions towards implementing constructivist approach are higher than those of female teachers. As the source of this result, we can say that the competencies of male teachers to use technology supported applications are better than those of female teachers. The research on elementary school teachers by Eskici (2013) supports this result.

When the self-efficacy perceptions of Turkish language and literature teachers regarding the constructivist approach were examined according to the type of faculty graduated, a significant difference was observed in the dimensions of activating student, encouraging thinking and guiding. When the source of the difference is analyzed, it is concluded that Turkish language and literature teachers, who are graduates of faculty of education, have better perceptions towards applying constructivist approach compared to other faculty graduates. The results of Coşkun (2012), Karaşahin and Kahyaoğlu (2011) support this result. Based on the research findings, we can say that the field knowledge, etc. that teachers who graduate from education faculties have are effective in the implementation of the constructivist approach. 
It was concluded that the perceptions of teachers about constructivist teaching differ significantly in the encouraging thinking and alternative assessment dimensions according to their participation in in-service education, yet not in terms of the guiding and activating student dimensions. We can say based on the findings of this research that the in-service trainings that teachers attended affect the self-efficacy perceptions towards the constructivist approach at a certain level. Studies in the literature (Eskici, 2013; Karadağ et al., 2008; Ziegler, 2000) support this result.

Another result obtained in the research is that Turkish language and literature teachers' self-efficacy perceptions do not differ according to having computer or information technology courses during their undergraduate education.

When the perceptions of teachers about implementing the constructivist approach according to the professional seniority variable were analyzed, it was seen that they differed significantly in terms of encouraging thinking, alternative assessment and guiding dimensions. There was no difference in the dimension of activating student. It was concluded from the research findings that the increase in professional seniority significantly affected the perception towards the constructivist approach. In similar studies conducted by Turan (2007) and Y1lmaz (2006), similar results were obtained in terms of the professional seniority variable.

When the self-efficacy perceptions of Turkish language and literature teachers regarding the constructivist approach are examined according to the type of school in which they work, it is concluded that the school types they work significantly affect the self-efficacy perceptions of the Turkish language and literature teachers towards the constructivist approach. It was concluded the perception of the teachers working in high-scoring schools such as science and social sciences that accept students with central placement scores towards applying constructivist approach are higher.

\section{Implications}

In line with the results obtained, it can be recommended that studies should be conducted to reveal how teachers' perceptions and skills towards implementing a constructivist approach can be increased and practical studies should be carried out on constructivist approach both before and in-service trainings. In addition, researches can be conducted in which experimental methods and techniques will be applied experimentally and the results will be shared.

\section{References}

Akınoğlu, O. (2012). Yapılandırmacılık (2. Baskı). In B. Oral (Ed.), Öğrenme öğretme kuram ve yaklaşımları içinde (pp. 429-444). Ankara: Prgem Akademi. https://doi.org/10.14527/9786053641827.17

Altun, S., \& Çolak, E. (2011). Öğrenme kuramları. S. Fer (Ed.), Öğrenme öğretme kuram ve yaklaşımları içinde. Ankara: Anı Yayıncılık.

Coşkun, K. (2012). Din kültürü ve ahlak bilgisi öğretmenlerinin yapılandırmacı yöntem yeterliklerinin çeşitli değişkenler açısından incelenmesi. Ĕgitim ve Öğretim Araştırmaları Dergisi, 1(4), 266-276.

Eskici, M., \& Özen R. (2013). Öğretmenlerin yapılandırmacı yaklaşımı uygulamaya yönelik öz yeterlik inanç ölçeği’nin uyarlanması. Adnan Menderes Üniversitesi Ĕgitim Fakültesi Eğitim Bilimleri Dergisi, 4(2), 19-29.

Eskici, M. (2013). İlköğretim öğretmenlerinin yapılandırmacı yaklaşıma iliş̧kin öz yeterlik algıları ile tutumları. Abant İzzet Baysal Üniversitesi Eğitim Bilimleri Enstitüsü, Yayımlanmamış Doktora tezi.

Karadağ, E., Deniz, S., Korkmaz, T., \& Deniz, G. (2008). Yapılandırmacı öğrenme yaklaşımı: Sınıf öğretmenlerinin görüşleri kapsamında bir araştırma. Uludağ Üniversitesi Eğitim Fakültesi Dergisi, 21(2), 383-402.

Karaşahin, A., \& Kahyaoğlu, H. (2011). Illköğretim birinci kademe fen ve teknoloji dersine giren 4. ve 5. sinıf ögretmenlerinin yapılandırmacı ögrenme modeli konusunda yeterliklerinin incelenmesi. X. Ulusal Fen Bilimleri ve Matematik Eğitim Kongresi 27-30 Haziran, Niğde.

Karasar, N. (2009). Bilimsel araştırma yöntemi. Ankara: Nobel Yayıncılık.

Koç, G. (2006). Yapılandırmacı Sınıflarda Öğretmen - Öğrenen Rolleri ve Etkileşim Sistemi. Eğitim ve Bilim, 31(142), 56-64.

Koç, G., \& Demirel, M. (2004). Davranış̧̧1ıktan yapılandırmacılı̆ga: eğitimde yeni bir paradigm. Hacettepe Üniversitesi Eğitim Fakültesi Dergisi, 27, 174-180.

Oğuz, A. (2009). Öğretmen eğitimi programlarındaki uygulamaların yapılandırmacı yaklaşıma uygunluğunun öğretmen adayı görüşleriyle değerlendirilmesi. Ankara Üniversitesi Eğitim Bilimleri Fakültesi Dergisi, 
42(1), 129-155.

Schunk, D. H. (2014). Eğitimsel bir bakışla öğrenme teorileri (5. Basımdan Çeviri). M. Şahin (Çev. Ed.), Ankara: Nobel Akademik Yayıncılık.

Taşpınar, M. (2017). Kuramdan uygulamaya öğretim ilke ve yöntemleri (8. Baskı). Ankara: Pegem Akademi. https://doi.org/10.14527/9786052411032

Yıldızlar, M. (2009). Öğretim ilke ve yöntemleri. Ankara: Pegem Akademi. https://doi.org/10.14527/9786055885984

Ziegler, J. F. (2000). Constructivist views of teaching, learning and supervising held by public school Teachers and their influence on student achievement in mathematics (Unpublished dissertation). Indiana University of Pennsylvania.

\section{Copyrights}

Copyright for this article is retained by the author(s), with first publication rights granted to the journal.

This is an open-access article distributed under the terms and conditions of the Creative Commons Attribution license (http://creativecommons.org/licenses/by/4.0/). 